\title{
Antioxidant capacities and $\beta$-glucan content of ethanol extract from Phellinus baumii
}

\author{
Hyun-Kyung Bae ${ }^{1}$, In-Wook Hwang ${ }^{2}$, Hee-Do Hong ${ }^{3}$, Shin-Kyo Chung ${ }^{1,2 *}$ \\ ${ }^{1}$ School of Food Science and Biotechnology, Kyungpook National University, Daegu 41566, Korea \\ ${ }^{2}$ Food and Bio-Industry Research Institute, Kyungpook National University, Daegu 41566, Korea \\ ${ }^{3}$ Korea Food Research Institute, Seongnam 13539, Korea
}

\section{상황버섯(Phellinus baumi) 에탄올 추출물의 항산화능과 $\beta$-glucan 함량}

\author{
배현경 ${ }^{1} \cdot$ 황인욱 $^{2} \cdot$ 홍희도 $^{3} \cdot$ 정신교 $^{1,2 *}$ \\ ${ }^{1}$ 경북대학교 식품공학부, ${ }^{2}$ 경북대학교 식품생물산업연구소, ${ }^{3}$ 한국식품연구원
}

\begin{abstract}
Phellinus baumii has been used in traditional oriental medicine for the treatment of various cancer types, such as lung cancer, ovarian cancer and malignant melanoma. It has strong anti-cancer, anti-inflammatory and antioxidant activities due to its polysaccharides including glucan, schizophyllan, heteroglycan and lentinan, as well as its polyphenolics such as protocatechuic acid, caffeic acid, coumaric acid. $\beta$-Glucan and polyphenolics may be the most important activ ecompounds in $P$. baumii. Therefore, researchers have focused on these two compounds to improve their contents in extracts. In this study, $P$. baumii was extracted with hot-water and ethanol at different pH conditions, and their $\beta$-glucan contents, antioxidant activity and antioxidant contents were determined. Extraction yield was highest for the $60 \%$ ethanol extract at $\mathrm{pH} 4$. The $\beta$-glucan contents of the hot-water extract at $\mathrm{pH} 7$ was higher than those of the ethanol extracts. The antioxidant contents and antioxidant activities of the ethanol extracts were higher than those of the hot-water extracts. Extraction with $60 \%$ ethanol at $\mathrm{pH} 7$ was appropriate with respect to the antioxidant capacities.
\end{abstract}

Key words : Phellinus baumii, alcohol extraction, $\beta$-glucan, antioxidant

\section{서 론}

상황버섯(Phellinus baumii)은 분류학적으로 소나무 비늘 버섯과 진흙버섯속에 속하며, 뽕나무와 활엽수의 줄기에 자생하는 버섯으로 초기에는 노란 진휽덩이가 뭉친 것 같은 형태로 자란다 $(1,2)$. 상황버섯은 소화기계 암, 폐암, 난소암, 악성 흑색종 등에 대한 항암활성과 면역증강 및 항산화 효과 등의 약리효과가 있어 건강식품 및 의약품 소재로 많이 이용되고 있다 $(3,4)$. 최근 연구에서는 아토피 피부염

*Corresponding author. E-mail : kchung@knu.ac.kr, Phone : 82-53-950-5778, Fax : 82-53-950-6772

Received 10 July 2015; Revised 16 September 2015; Accepted 21 September 2015.

Copyright (c) The Korean Society of Food Preservation. All rights reserved.
에서 임상적 치료 효과(5), 식후 혈당 상승 억제 효과(6), 지방소화효소 억제 효과(7)에 대한 보고가 있으며, 이러한 상황버섯의 항암활성, 면역 증강 및 항염증 작용은 polysaccharide, 항산화 활성은 폴리페놀성 화합물로부터 기인한 것이다(8).

버섯의 polysaccharide에는 glucan, schizophyllan, heteroglycan, lentinan, krestin 및 galactomannan등이 있고(9), 이 중 $\beta$ -glucan은 bacteria와 fungus의 세포벽 내에 가장 많이 존재 하는 polysaccharide로, 대식세포에서 방출되는 TNF- $a$ 를 조절하여 염증반응을 억제하고, 정상적인 면역세포의 기능 을 활성화하여 암세포 증식과 재발을 억제한다고 알려져 있다(10-12). 그리고 상황버섯의 폴리페놀성 화합물에는 protocatechuic acid, caffeic acid, coumaric acid, hispidin, hispidin dimer, 3,14' -bihispidinyl, hypholomine $\mathrm{B}$ 및 1,1-distyrylpyrylethan등이 보고되어 있다 $(13,14)$. 
그리고 Lee 등(13)은 에탄올 농도에 따른 폴리페놀화합 물 함량과 생리활성 측정, Park과 Hong(15)은 열수, 초음파, 가압추출방법에 따른 항산화 성분 및 항산화 활성 비교, Youn 등(16)은 추출시간 및 가수량에 따른 열수추출액의 품질특성을 보고하였다.

본 연구에서는 물 및 에탄올 농도, $\mathrm{pH}$ 를 달리하여 상황버 섯 추출물을 제조하여 $\beta$-glucan 함량과 항산화 활성 및 성분 의 함량을 조사하여 보고하는 바이다

\section{재료 및 방법}

\section{실험 재료 및 시약}

실험에 사용한 상황버섯(Phellinus baumii)은 경상북도 안동시 임하면 (주)류충현 약용버섯에서 재배된 2년산 버섯 을 공여받아 사용하였다. Gallic acid, trolox, rutin, 1,1diphenyl-2-picrylhydrazyl(DPPH),2,4,6-tris(2-pyridyl)-1,3,5triazine(TPTZ)는 Sigma chemical Co.(St. Louis. Mo, USA)의 제품을 사용하였고, 그 외에 ethanol, citric acid, sodium hydroxide, sodium acetate, potassium hydroxide, hydrochloric acid 는 분석용 1급 시약(Duksan Co., Seoul, Korea)을 사용 하였다.

\section{상황버섯 추출}

상황버섯을 일정한 크기 $(1 \times 1 \mathrm{~cm})$ 로 절단한 후 분쇄하여 $25 \mathrm{mesh}$ 를 통과한 입자를 분석용 시료로 사용하였다. 상황 버섯 분말 $1 \mathrm{~g}$ 당 추출용매 $20 \mathrm{~mL}$ 를 가하여, $90^{\circ} \mathrm{C}$ 에서 3 , $6,12,24,48$ 시간 동안 환류 추출하였다. 추출용매는 물 및 ethanol $(30,60,90 \%)$ 을 사용하였고, citric acid와 sodium hydroxide를 이용하여 $\mathrm{pH}$ 를 $4,7,10$ 으로 조정하여 실험에 사용하였다.

\section{추출수율 측정}

상황버섯 추출물 $5 \mathrm{~mL}$ 를 dry oven을 이용하여 $105^{\circ} \mathrm{C}$ 에서 증발 건조 시킨 후 남은 고형분의 항량을 구하여 원시료량 에 대한 백분율(\%)로써 추출수율을 나타내었다.

\section{$\beta$-glucan 함량 측정}

$\beta$-glucan 함량은 $\beta$-D-glucan assay kit(Megazyme, Wicklow, Ireland)를 이용하여 분석하였다(11). Total glucan 함량과 a-glucan 함량을 구하여 total glucan에서 a-glucan을 제외한 값을 $\beta$-glucan 함량으로 하였다. 상황버섯 추출물 고형분 $20 \mathrm{mg}$ 에 $\mathrm{HCl} 1.5 \mathrm{~mL}(37 \%)$ 를 가하여 $30^{\circ} \mathrm{C}$ 에서 45 분간 반응 시키고 증류수 $10 \mathrm{~mL}$ 를 가한 후 $100^{\circ} \mathrm{C}$ 에서 2시간 가열하였 다. 반응액에 $2 \mathrm{~N} \mathrm{KOH} 10 \mathrm{~mL}$ 를 가하고 $0.2 \mathrm{M}$ sodium acetate buffer(pH 5.0)로 $100 \mathrm{~mL}$ 로 정량한 후 Whatman GF/A glass microfiber filter(GE Healthcare, Amersham, UK)
로 여과 하였다. 여과액 $0.1 \mathrm{~mL}$ 에 exo-1,3- $\beta$-glucanase + $\beta$-glucosidase $0.1 \mathrm{~mL}$ 를 혼합하여 $40^{\circ} \mathrm{C}$ 에서 60 분간 반응시 켰다. 반응액에 glucose oxidase/peroxidase mixture(GOPOD) $3 \mathrm{~mL}$ 를 넣고 $40^{\circ} \mathrm{C}$ 에서 20 분간 반응시킨 후 microplate reader(Emax precision, Molecular devices, Sunnyvale, CA, USA)로 $510 \mathrm{~nm}$ 에서 흡광도를 측정하여total glucan 함량으 로 하였다. a-Glucan 함량은 고형분 $20 \mathrm{mg}$ 에 $2 \mathrm{~N} \mathrm{KOH}$ $2 \mathrm{~mL}$ 을 혼합하여 20분간 현탁하고, $1.2 \mathrm{M}$ sodium acetate buffer(pH 3.8) $8 \mathrm{~mL}$ 와 amyloglucosidase + invertase $0.2 \mathrm{~mL}$ 를 넣고 혼합 후 $40^{\circ} \mathrm{C}$ 에서 30 분간 반응시켜, 반응액 0.1 $\mathrm{mL}$ 와 $200 \mathrm{mM}$ sodium acetate buffer( $\mathrm{pH} 5.0) 0.1 \mathrm{~mL}$, GOPOD $3.0 \mathrm{~mL}$ 를 혼합 후 $40^{\circ} \mathrm{C}$ 에서 20 분간 반응시키고, $510 \mathrm{~nm}$ 에서 흡광도 측정하여 구하였다.

\section{DPPH free radical 소거활성 측정}

DPPH free radical 소거활성은 Blois의 방법(17)으로 측정 하였다. 시료 $20 \mu \mathrm{L}$ 와 $200 \mu \mathrm{M} \mathrm{DPPH}$ 용액 $180 \mu \mathrm{L}$ 를 혼합하 고, 암실에서 30 분간 방치한 후 $490 \mathrm{~nm}$ 에서 흡광도를 측정 하여 구하였다.

Ferric ion reducing antioxidant power(FRAP) 측정

FRAP 활성은 Benzie 등의 방법(18)을 변용하여 측정하 였다. 반응용액(cocktail solution)은 acetate buffer(pH 3.6, $300 \mathrm{mM}$ ), $10 \mathrm{mM}$ TPTZ(2,4,6-tripyridyls-triazine) 및 $20 \mathrm{mM}$ ferric chloride solution를 $10: 1: 1$ 의 비율로 혼합하여 사용 하였다. 시료 $25 \mu \mathrm{L}$ 와 cocktail solution $175 \mu \mathrm{L}$ 를 혼합하여 암실에서 30 분간 방치한 후 $650 \mathrm{~nm}$ 에서 흡광도를 측정하였 다. 결과는 trolox의 검량선의 회귀식을 이용하여 trolox equivalent $\mathrm{mM}(\mathrm{TE} \mathrm{mM})$ 로 나타내었다.

\section{총페놀성 화합물 함량 측정}

총페놀성 화합물 함량은 Folin-Ciocalteu regent 시약을 이용하여 측정하였다(19). 시료 $100 \mu \mathrm{L}$ 에 2 N Folin-Ciocalteau 시약 $50 \mu \mathrm{L}$ 와 $20 \%$ sodium carbonate $300 \mu \mathrm{L}$ 를 가하여 실온 에서 15 분간 방치한 후 증류수 $1 \mathrm{~mL}$ 을 넣고 원심분리한 후 상등액을 $725 \mathrm{~nm}$ 에서 흡광도를 측정하였다. 결과는 gallic acid 검량선의 회귀식을 이용하여 gallic acid equivalent(GAE $\mathrm{g} / \mathrm{L})$ 로 환산하여 나타내었다.

\section{총플라보노이드 함량 측정}

총플라보노이드 함량은 $\mathrm{Jia}$ 등의 방법(20)을 응용하여 측정하였다. 시료 $70 \mu \mathrm{L}$ 에 $50 \%$ ethanol $430 \mu \mathrm{L}$ 를 가하고 $5 \%$ sodium nitrite $50 \mu \mathrm{L}$ 를 넣고 혼합한 후 20분 동안 상온에 서 반응시켰다. $10 \%$ aluminium nitrate nonahydrate $50 \mu \mathrm{L}$ 를 넣고 다시 상온에서 6 분간 반응시킨 후 $1 \mathrm{~N}$ sodium hydroxide을 $500 \mu \mathrm{L}$ 가하여, $510 \mathrm{~nm}$ 에서 흡광도를 측정하였 다. 결과는 catechin 검량선의 회귀식을 이용하여 catechin 
equivalent(CE g/L)로 환산하여 나타내었다.

\section{통계처리}

모든 실험은 3회 반복하여 실시하였으며, 값은 평균 \pm 표 준편차로 나타내었으며, SAS(9.3, SAS Institute Inc., Cary, $\mathrm{NC}, \mathrm{USA}$ )를 이용하여 분산분석과 Duncan의 다중범위검정 법으로 유의성을 검정하였다 $(\mathrm{p}<0.05)$.

\section{결과 및 고찰}

\section{추출조건에 따른 수율과 $\beta$-glucan 함량}

추출시간에 따른 상황버섯의 수율과 $\beta$-glucan 함량 측정 의 결과는 Fig. 1 에 나타내었다. 상황버섯의 수율은 추출시 간이 길어질수록 증가하여, 3 시간에서 12 시간까지 수율이 $0.51 \% \mathrm{p}$ 증가하였고, 12 시간에서 24 시간까지 $1.25 \% \mathrm{p}$ 증가 하였다. 그리고 24 시간에서 48 시간까지 $0.72 \% \mathrm{p}$ 증가하여 증가율이 감소하였다. $\beta$-Glucan 함량은 $3,6,12$ 시간 추출에 서 30.19 31.30\%이고, 12 시간 추출에서 $35.27 \%$ 로 약 $4.40 \% \mathrm{p}$ 증가하였다. 그리고 48 시간 추출 시 $\beta$-glucan 함량 이 $46.51 \%$ 로 12 시간 추출보다 $11.23 \% \mathrm{p}$ 증가하였으나, 시간 이 길어진 것에 비해 $\beta$-glucan 함량 증가율은 높지 않으므 로, 수율과 $\beta$-glucan 함량의 결과를 보아 추출시간이 24 시간 이 적합하다고 판단하였다. Park 등(21)과 Lee(13)에 의하면 추출용매의 $\mathrm{pH}$ 와 에탄올 농도에 따른 $\beta$-glucan 함량과 활성 에 차이를 보인다고 보고 하였다.

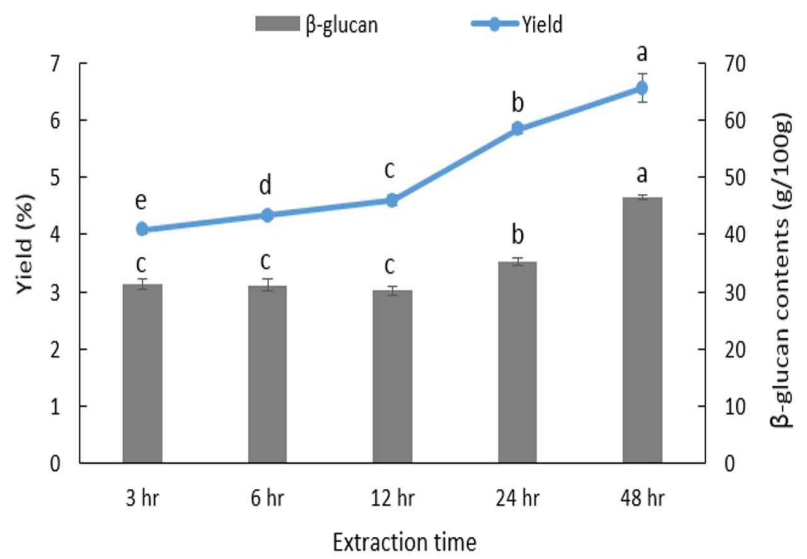

Fig. 1. Yields and $\beta$-glucan contents of Phellinus baumii extracts depending on the extraction time.

Line, extraction yield; Bar, $\beta$-glucan contents. Values represent the mean $\pm S D(n=3)$. Means with same letters are not significantly different at $p<0.05$.

상황버섯 추출물의 추출용매에 따른 수율측정 결과는 Table 1에 나타내었다. 추출물의 수율은 에탄올 농도 $60 \%$ 까 지 수율이 증가하다가 $90 \%$ 에서 감소하였다. $60 \%$ 에탄올, $\mathrm{pH} 4$ 의 조건에서 $12.08 \%$ 로 수율이 가장 높았고, 열수, $\mathrm{pH}$
7 조건에서 $4.08 \%$ 로 가장 수율이 낮았다. 전반적으로 $\mathrm{pH}$

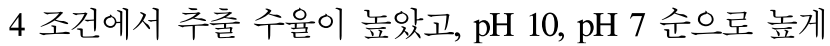
나타났다. 상황버섯은 추출효율이 낮은 경질버섯으로 다른 일반버섯에 비하여 추출 수율이 낮다. Choi 등(8)은 상황버 섯과 주요 식용버섯 추출물의 수율을 비교하여 상황버섯이 다른 버섯에 비해 낮은 수율을 나타내었다고 보고한 바 있다. 추출용매에 따른 $\beta$-glucan 함량의 결과는 Table 2 에 나타내었다. $\beta$-glucan 함량은 에탄올의 농도가 증가할수록 낮아지는 경향을 보였고, 열수 추출물에서 $32.64( \pm 0.83)$ $\sim 35.39( \pm 0.03) \mathrm{g} / 100 \mathrm{~g}$ 으로 에탄올 추출물의 $22.95( \pm 0.76)$ $\sim 26.87( \pm 0.63) \mathrm{g} / 100 \mathrm{~g}$ 보다 높았다. 그리고 $\mathrm{pH} 10$ 보다 $\mathrm{pH}$ 4 와 $\mathrm{pH} 7$ 조건에서 추출한 것이 높은 함량을 나타내었다. 실험에 사용한 상황버섯 원시료의 $\beta$-glucan 함량이 24.15 $\pm 0.26 \mathrm{~g} / 100 \mathrm{~g}$ 인 것과 비교하면 열수 추출물의 경우 약 1.5 배 증가하였다. 에탄올 추출물의 경우 원시료 보다 함량이 더 낮게 나타난 것은 상황버섯에는 water-soluble $\beta$-glucan이 insoluble $\beta$-glucan보다 많기 때문이다(22). $\beta$-Glucan은 bacteria와 fungus의 세포벽 내에 존재하는 다당류 중 가장 많이 존재하고 있으나, $\beta$-glucan을 추출하는 것은 쉽지 않 고, 추출 및 정제된 $\beta$-glucan 내에 다른 기타 성분들이 일부 혼입되어 있다고 알려져 있다 $(8,10,23)$. Lee 등(24)은 귀리 의 B-glucan은 중성조건일 때 보다 산성이나 알칼리조건에 서 더 많은 함량의 $\beta$-glucan이 추출되었다고 보고하였고, 본 연구에서는 상황버섯의 경우 산성조건에서 추출된 $\beta$ -glucan의 함량이 높게 나타났다. 그리고 탄화텅스텐 소재

Table 1. Extraction yields of Phellinus baumii extracts depending on extraction condition

\begin{tabular}{cccc}
\hline \multirow{2}{*}{$\begin{array}{c}\text { Ethanol conc. } \\
(\%)\end{array}$} & \multicolumn{3}{c}{ Extraction yield $(\%)$} \\
\cline { 2 - 4 } & $\mathrm{pH} 4$ & $\mathrm{pH}$ & $\mathrm{pH} 10$ \\
\hline 0 & $5.95 \pm 0.22^{\mathrm{aDl} 1)}$ & $4.08 \pm 0.07^{\mathrm{CC}}$ & $4.89 \pm 0.05^{\mathrm{bD}}$ \\
30 & $8.44 \pm 0.17^{\mathrm{bC}}$ & $8.04 \pm 0.14^{\mathrm{bB}}$ & $8.97 \pm 0.05^{\mathrm{aC}}$ \\
60 & $12.08 \pm 0.11^{\mathrm{aA}}$ & $11.74 \pm 0.14^{\mathrm{abA}}$ & $9.89 \pm 0.16^{\mathrm{bA}}$ \\
90 & $9.31 \pm 0.12^{\mathrm{aB}}$ & $7.49 \pm 0.02^{\mathrm{bB}}$ & $9.45 \pm 0.17^{7^{\mathrm{B}}}$ \\
\hline
\end{tabular}

1)abcd Mean \pm SD ( $n=3)$ within each row followed by the same letter are not significantly different $(\mathrm{p}<0.05) ;{ }^{\mathrm{ABCD}}$ mean $\pm \mathrm{SD}(\mathrm{n}=3)$ within each column followed by the same letter are not significantly different $(\mathrm{p}<0.05)$.

Table 2. $\beta$-Glucan contents of Phellinus baumii extracts depending on extraction conditions

\begin{tabular}{cccc}
\hline $\begin{array}{c}\text { Ethanol } \\
\text { conc. } \\
(\%)\end{array}$ & \multicolumn{3}{c}{ B-Glucan contents (g/100 g dry weight basis) } \\
\cline { 2 - 4 } & $\mathrm{pH} 4$ & $\mathrm{pH} 7$ & $\mathrm{pH} 10$ \\
\hline 0 & $35.39 \pm 0.03^{\mathrm{aAl}}$ & $35.27 \pm 0.64^{\mathrm{aA}}$ & $32.64 \pm 0.83^{\mathrm{bA}}$ \\
30 & $26.57 \pm 0.17^{\mathrm{aB}}$ & $26.87 \pm 0.63^{\mathrm{aB}}$ & $25.43 \pm 0.92^{\mathrm{aB}}$ \\
60 & $25.32 \pm 0.64^{\mathrm{aBC}}$ & $25.08 \pm 1.63^{\mathrm{aB}}$ & $23.09 \pm 0.85^{\mathrm{aC}}$ \\
90 & $24.64 \pm 0.40^{\mathrm{bC}}$ & $26.85 \pm 0.74^{\mathrm{aB}}$ & $22.95 \pm 0.76^{\mathrm{bC}}$ \\
\hline
\end{tabular}

1)abcc Mean $\pm \mathrm{SD}(\mathrm{n}=3)$ within each row followed by the same letter are not significantly different $(\mathrm{p}<0.05)$; ${ }^{\mathrm{ABC} D}$ mean $\pm \mathrm{SD}(\mathrm{n}=3)$ within each column followed by the same letter are not significantly different $(\mathrm{p}<0.05)$. 
의 nano입자를 이용하여 $\beta$-glucan을 추출한 Park 등(21)의 보고에서도 알칼리조건에서 더 높은 $\beta$-glucan함량을 보였 고, 30 시간 추출 시 $\beta$-glucan함량이 약 $60 \%$ 로 본 연구보다 더 높은 함량을 나타내었다.

\section{상황버섯 추출물의 항산화활성}

$\mathrm{DPPH}$ free radical 소거활성은 free radical을 직접적으로 소거하는 것에 의하여 항산화활성을 측정하는 방법으로 안정한 free radical인 DPPH가 전자를 공여할 수 있는 항산 화 물질과 반응하게 되면 자색에서 무색으로 변화되는 메카 니즘을 이용한 방법이다(17). FRAP 활성은 DPPH free radical 소거활성과 달리 산화 및 환원 반응에 의해 항산화활 성을 측정하는 방법으로 ferric complex가 항산화 물질에 의해 ferrous complex로 환원되는 메카니즘을 이용한 방법 이다(18). 따라서 시료에 함유된 항산화 물질의 종류, 분포 및 생화학적 특성에 따라 결과가 상이하게 나타날 수 있으 므로 두 활성 측정법 모두를 이용한 항산화활성 측정이 요구된다(25). 상황버섯 추출물의 DPPH free radical 소거활 성과 FRAP 활성 측정의 결과는 Table 3 에 나타내었다. DPPH free radical 소거활성 결과 열수 추출물이 10.04 $( \pm 0.25) \sim 12.31( \pm 0.25) \%, 30 \%$ 에탄올 추출물이 $44.10( \pm 0.68)$ $\sim 52.80( \pm 0.77) \%, 60 \%$ 에탄올 추출물이 $68.04( \pm 0.14)$ $73.76( \pm 0.25) \%, 90 \%$ 에탄올 추출물이 $51.97( \pm 0.96) 62.49$ $( \pm 0.00)$ 로 에탄올 추출물이 열수 추출물에 비해 약 5 6배 억제율이 높게 나타났다. 또한 $\mathrm{pH} 10$ 조건에서 추출한 것이
더 높은 항산화활성을 보였다. 이 결과는 Kwoen 등(26)의 열수 추출물 보다 에탄올 추출이 활성이 더 높다는 보고와 일치한다. 에탄올 농도에 따른 상황버섯의 DPPH free radical 소거활성을 측정한 Lee 등(13)의 보고에서는 에탄올 농도 $60 \%$ 까지 항산화활성이 증가하다가 $70 \%$ 부터는 큰 증가를 보이지 않았다. FRAP 활성은 DPPH free radical 소거활성의 결과와 유사하게 나타났다. 열수 추출물이 $1.61( \pm 0.00) \sim 2.03( \pm 0.04) \mathrm{TE} \mathrm{mM}, 30 \%$ 에탄올 추출물이 8.38( \pm 0.09$) ~ 10.68( \pm 0.09) \mathrm{TE} \mathrm{mM}, 60 \%$ 에탄올 추출물이 $15.60( \pm 0.11) 17.40( \pm 0.08) \mathrm{TE} \mathrm{mM}, 90 \%$ 에탄올 추출물이 9.41( \pm 0.10$) ~ 11.54( \pm 0.04) \mathrm{TE} \mathrm{mM}$ 의 활성을 나타내었다. $60 \%$ 에탄올 추출물이 열수 추출물에 비해 약 9 배 정도 높은 항산화활성을 보였고, $\mathrm{pH}$ 에 따른 활성 차이 또한 $\mathrm{DPPH}$ free radical 소거활성과 유사하였다. 따라서 상황버 섯의 항산화활성은 $60 \%$ 에탄올, $\mathrm{pH} 7$ 조건의 추출물에서 가장 높은 값을 나타내었다.

\section{상황버섯 추출물의 항산화성분}

식물체에서 폴리페놀화합물과 같은 phytochemical은 주 위 환경으로부터 식물체를 보호하는데 중요한 역할을 하는 이차 대사산물로서 항산화활성, 항염증 활성, 항균 활성, 항암 활성 등 다양한 생리활성을 가지며(27), 품종, 수확시 기, 생육 지역, 추출 방법에 따라 함량의 차이를 보인다(28). 상황버섯과 같은 경우에는 생물을 그대로 섭취하기 보다는 보통 뜨거운물에 추출하여 차의 형태로 섭취하게 된다. 따

Table 3. Antioxidant activities of Phellinus baumii extracts depending on extraction conditions

\begin{tabular}{ccccccc}
\hline \multirow{2}{*}{$\begin{array}{c}\text { Ethanol conc. } \\
(\%)\end{array}$} & \multicolumn{3}{c}{$\mathrm{DPPH}^{\mathrm{l})}(\%$ inhibition $)$} \\
\cline { 2 - 7 } & $\mathrm{pH} 4$ & $\mathrm{pH}$ & $\mathrm{pH} 10$ & $\mathrm{pH} 4$ & $\mathrm{pH} 7$ & $\mathrm{pH} 10$ \\
\hline 0 & $10.72 \pm 0.34^{\mathrm{bD2}}$ & $10.04 \pm 0.25^{\mathrm{CD}}$ & $12.31 \pm 0.25^{\mathrm{aD}}$ & $1.76 \pm 0.07^{\mathrm{bD}}$ & $1.61 \pm 0.00^{\mathrm{CD}}$ & $2.03 \pm 0.04^{\mathrm{aD}}$ \\
30 & $48.00 \pm 0.14^{\mathrm{bC}}$ & $44.10 \pm 0.68^{\mathrm{CC}}$ & $52.80 \pm 0.77^{\mathrm{aC}}$ & $8.38 \pm 0.09^{\mathrm{CC}}$ & $8.58 \pm 0.08^{\mathrm{bC}}$ & $10.68 \pm 0.09^{\mathrm{aC}}$ \\
60 & $70.39 \pm 0.30^{\mathrm{bA}}$ & $73.76 \pm 0.25^{\mathrm{AA}}$ & $68.04 \pm 0.14^{\mathrm{cA}}$ & $16.85 \pm 0.08^{\mathrm{bA}}$ & $17.40 \pm 0.08^{\mathrm{aA}}$ & $15.60 \pm 0.11^{\mathrm{cA}}$ \\
90 & $51.97 \pm 0.96^{\mathrm{CB}}$ & $54.74 \pm 0.63^{\mathrm{bB}}$ & $62.49 \pm 0.00^{\mathrm{aB}}$ & $9.41 \pm 0.10^{\mathrm{B}}$ & $9.94 \pm 0.10^{\mathrm{bB}}$ & $11.54 \pm 0.04^{\mathrm{aB}}$ \\
\hline
\end{tabular}

${ }^{1)} \mathrm{DPPH}, 1,1-$ diphenyl-1-picrylhydrazyl; FRAP, ferric ion reducing antioxidant power; TE, trolox equivalent.

2)abcd Mean $\pm \mathrm{SD}(\mathrm{n}=3)$ within each row followed by the same letter are not significantly different $(\mathrm{p}<0.05) ;{ }^{\mathrm{ABC}}{ }_{\text {mean }} \pm \mathrm{SD}(\mathrm{n}=3)$ within each column followed by the same letter are not significantly different $(\mathrm{p}<0.05)$.

Table 4. Antioxidant contents of Phellinus baumii extracts depending on extraction conditions

\begin{tabular}{|c|c|c|c|c|c|c|}
\hline \multirow{2}{*}{$\begin{array}{c}\text { Ethanol conc. } \\
(\%)\end{array}$} & \multicolumn{3}{|c|}{$\mathrm{TPC}^{1)}(\mathrm{GAE} \mathrm{g} / \mathrm{L})$} & \multicolumn{3}{|c|}{ TFC (CE g/L) } \\
\hline & $\mathrm{pH} 4$ & $\mathrm{pH} 7$ & $\mathrm{pH} 10$ & $\mathrm{pH} 4$ & pH 7 & $\mathrm{pH} 10$ \\
\hline 0 & $0.37 \pm 0.01^{(\mathrm{D} 2)}$ & $0.29 \pm 0.01^{\mathrm{cD}}$ & $0.35 \pm 0.00^{\mathrm{bD}}$ & $0.25 \pm 0.00^{\mathrm{bD}}$ & $0.28 \pm 0.00^{\mathrm{aD}}$ & $0.24 \pm 0.00^{\mathrm{CD}}$ \\
\hline 30 & $1.11 \pm 0.01^{\mathrm{bC}}$ & $1.08 \pm 0.01^{\mathrm{cC}}$ & $1.33 \pm 0.02^{\mathrm{aC}}$ & $1.00 \pm 0.000^{\mathrm{bC}}$ & $0.93 \pm 0.01^{C^{C}}$ & $1.08 \pm 0.01^{\mathrm{aC}}$ \\
\hline 60 & $2.05 \pm 0.01^{\mathrm{bA}}$ & $2.16 \pm 0.01^{\mathrm{aA}}$ & $1.78 \pm 0.02^{\mathrm{cA}}$ & $1.70 \pm 0.01^{\mathrm{bA}}$ & $1.74 \pm 0.01^{\mathrm{aA}}$ & $1.49 \pm 0.01^{\mathrm{cB}}$ \\
\hline 90 & $1.18 \pm 0.03^{\mathrm{bB}}$ & $1.19 \pm 0.01^{\mathrm{bB}}$ & $1.38 \pm 0.02^{\mathrm{aB}}$ & $1.28 \pm 0.01^{\mathrm{cB}}$ & $1.27 \pm 0.05^{\mathrm{bB}}$ & $1.50 \pm 0.01^{\mathrm{aA}}$ \\
\hline
\end{tabular}

\footnotetext{
${ }^{1)} \mathrm{TPC}$, total phenolic contents; TFC, total flavonoid contents; GAE, gallic acid equivalent; CE, catechin equivalent.

2)abcd Mean $\pm S D(n=3)$ within each row followed by the same letter are not significantly different $(\mathrm{p}<0.05) ;{ }^{A B C D}$ mean $\pm S D(n=3)$ within each column followed by the same letter are not significantly different $(\mathrm{p}<0.05)$
} 
라서 추출 방법이 상황버섯 추출물의 생리활성 물질 함량에 큰 영향을 주므로, 본 연구에서는 물, 에탄올과 $\mathrm{pH}$ 조건에 따른 상황버섯 추출물의 총페놀성 화합물 함량과 총플라보 노이드 함량을 측정하였고, 결과는 Table 4에 나타내었다. 총페놀성 화합물 함량은 열수 추출물이 $0.29( \pm 0.01) \sim 0.37$ $( \pm 0.01) \mathrm{GAE} \mathrm{g} / \mathrm{L}, 30 \%$ 에탄올 추출물이 $1.08( \pm 0.01)$ $1.33( \pm 0.02) \mathrm{GAE} \mathrm{g} / \mathrm{L}, 60 \%$ 에탄올 추출물이 $1.78( \pm 0.02)$ $2.16( \pm 0.01) \mathrm{GAE} \mathrm{g} / \mathrm{L}, 90 \%$ 에탄올 추출물이 $1.18( \pm 0.03)$ 1.38( \pm 0.02$) \mathrm{GAE} \mathrm{g/L로} 60 \%$ 에탄올 추출물에서 가장 높았 고, 가장 낮은 열수 추출물에 비해 약 6배 높게 나타났다. 총플라보노이드 함량은 열수 추출물이 $0.24( \pm 0.00) ~ 0.28$ $( \pm 0.00) \mathrm{CE} \mathrm{g} / \mathrm{L}, 30 \%$ 에탄올 추출물이 $0.93( \pm 0.01) \sim 1.08$ $( \pm 0.01) \mathrm{CE} \mathrm{g} / \mathrm{L}, 60 \%$ 에탄올 추출물이 $1.49( \pm 0.01) \sim 1.74$ $( \pm 0.01) \mathrm{CE} \mathrm{g} / \mathrm{L}, 90 \%$ 에탄올 추출물이 $1.27( \pm 0.05) \sim 1.50$ ( \pm 0.01$) \mathrm{CE} \mathrm{g} / \mathrm{L}$ 로 $60 \%$ 에탄올 추출물이 열수 추출물에 비해 약 8 배 이상 높았으며, $60 \%$ 에탄올 추출물이 가장 높았고, $90 \%$ 그리고 $30 \%$ 에탄올 추출물, 열수 추출물 순으로 함량 이 높다. 총페놀성 화합물과 총플라보노이드 함량은 $\mathrm{pH}$ 에 따른 유의적 차이는 보이지 않았다. 열수 추출물에 비해 에탄올 추출물에서 항산화 성분의 함량이 높다는 $\mathrm{Kim}$ 등 (29)의 연구결과와 유사하며, Lee 등(13)의 보고에서 에탄 올 농도에 따른 총페놀성 화합물 함량 측정 결과 $80 \%$ 까지 증가하다가 $90 \%$ 에서 함량이 감소하는 보고와 비슷한 결과 를 보였다.

\section{요 약}

상황버섯을 $90^{\circ} \mathrm{C}$ 에서 환류추출 시 시간과 추출용매의 조건(물 및 에탄올 농도, $\mathrm{pH}$ )에 따른 추출물을 제조하여 B-glucan 함량과 항산화활성 및 항산화성분의 함량을 조사 하였다. 상황버섯 추출물은 추출시간이 길어짐에 따라 수 율과 B-glucan 함량이 증가하여 24시간 추출 조건을 실험에 사용하였다. 추출용매에 따른 상황버섯 추출물의 수율은 $60 \%$ 에탄올, $\mathrm{pH}$ 4의 조건에서 가장 높았다. B-glucan 함량 은 열수 추출물에서 높은 함량을 나타내었고, 산성과 중성 조건에서 높게 나타났다. 항산화활성은 $60 \%$ 에탄올, $\mathrm{pH}$ 7 조건에서 추출한 것이 가장 높았다. 항산화성분의 함량 또한 항산화활성과 같은 경향을 보였으며, 수율, $\beta$-glucan 함량, 항산화활성 및 성분을 모두 고려하였을 때 $60 \%$ 에탄 올, $\mathrm{pH} 7$ 추출 조건이 적합하였다.

\section{감사의 글}

본 연구는 농림축산식품부 고부가가치 식품기술개발사 업에 의해 이루어진 것으로 연구비 지원에 감사드립니다.

\section{References}

1. Kim HR, Hong JS, Choi JS, Han GJ, Kim TY, Kim SB, Chun HK (2005) Properties of wet noodle changed by the addition of Sanghwang mushroom (Phellinus linteus) powder and extract. Korean J Food Sci Technol, 37, 579-583

2. Kim MS, Lee YH, Lim IY, Eom TK, Kim SH, Jo NJ, Yu SR, Jeong YH (2013) Physicochemical characteristics of Korean traditional spirits brewed with Phellinus linteus by different Nuruks. J Korean Soc Food Sci Nutr, 42, 2042-2048

3. Han KW, Lee SW, Han KS, Lee DJ, Lee BE, Jang WC (2003) Antitumor activities to cytotoxicity of Phellinus linteus ethanol extract. J Toxicol Pub Health, 19, 147-152

4. Kozarski M, Klaus A, Niksic M, Jakovljevic D, Helsper JPFG, Van Griensven LJLD (2011) Antioxidative and immunomodulating activities of polysaccharide extracts of the medicinal mushrooms Agaricus bisporus, Agaricus brasiliensis, Ganoderma lucidum and Phellinus linteus. Food Chem, 129, 1667-1675

5. Hong WK, Shin JH, Lee YH, Park DK, Choi GS (2008) The clinical effect of Phellinus linteus grown on germinated brown rice in the treatment of atopic dermatitis. Korean J Herbologym, 23, 103-108

6. Choi HY, Ha KS, Jo SH, Ka EH, Chang HB, Kwon YI (2012) Antioxidant and anti-hyperglycemic effects of a Sanghwang mushroom (Phellinus linteusau) water extract. Korean J Food Nutr, 25, 239-245

7. Kim JH, Son IS, Kim JS, Kim KH, Kwon CS (2008) Lipase-inhibitory and anti-oxidative activity of the methanol extract and the powder of Phellinus linteus. J Korean Soc Food Sci Nutr, 37, 154-161

8. Choi SJ, Lee YS, Kim JK, Kim JK, Lim SS (2010) Physiological activities of extract from edible mushrooms. J Korean Soc Food Sci Nutr, 39, 1087-1096

9. Kim HM, Lee DH (2010) Characterization of anti-inflammation effect of aqueous extracts from Phellinus baumii. Korean J Mycol, 32, 179-183

10. Chan GCF, Chan WK, Sze DMY (2009) The effects of $\beta$-glucan on human immune and cancer cells. $\mathbf{J}$ Hematol Oncol, 2, 25

11. Olson EJ, Standing JE, Griego-Harper N, Hoffman OA, Limper AH (1996) Fungal $\beta$-glucan interacts with vitronectin and stimulates tumor necrosis factor alpha release from macrophages. Infect Immun, 64, 3548-3554

12. Kang SA, Jang $\mathrm{KH}$, Hong $\mathrm{KH}$, Choi WA, Jung $\mathrm{KH}$, 
Lee IY (2002) Effects of dietary $\beta$-glucan on adiposity and serum lipid levels in obese rats induced by high fat diet. J Koraen Soc Food Sci Nutr, 31, 1052-1057

13. Lee KH, Kwon HJ, Chun SS, Kim JH, Cho YJ, Cha WS (2006) Biological activites of extracts from Phellinus linteus. J Korean Soc Appl Biol Chem, 49, 298-303

14. Jung JY, Lee IK, Seok SJ, Lee HJ, Kim YH, Yun BS (2008) Antioxidant polyphenols from the mycelial culture of the medicinal fungi Inonotus xeranticus and Phellinus linteus. J Appl Microbiol, 104, 1824-1832

15. Park HM, Hong JH (2014) Antioxidant activity of extracts with extraction methods from Phellinus linteus mycelium on Mori ramulus. Korean J Food Preserv, 21, 565-572

16. Youn SJ, Cho JG, Kwoen DJ, Choi UK, Kang SC (2006) Determination of optimal conditions by response surface methodology and quality characteristics of water extracts of Phellinus linteus. J Korean Soc Appl Biol Chem, 49, 215-220

17. Blois MS (1958) Antioxidants determination by the use of a stable free radical. Nature, 181, 1199-1200

18. Benzie IFF, Strain JJ (1996) The Ferric reducing ability of plasma (FRAP) as a measure of "antioxidant power" : the FRAP assay. Anal Biochem, 239, 70-76

19. Singleton VL, Orthofer R, Lamuela-Raventos RM (1999) Analysis of total phenolic and other oxidation substrates and antioxidants by means of Folin-Ciocalteu reagent. Methods Enzymol, 299, 152-17

20. Jia Z, Tang M, Wu J (1999) The determination of flavonoid contents in mulberry and their scavenging effect on superoxide radicals. Food Chem, 64, 555-559

21. Park HG, Shim YY, Choi SO, Park WM (2009) New method development for nanoparticle extraction of water-soluble $\beta-(1 \rightarrow 3)$-D-glucan from edible mushrooms, Sparassis crispa and Phellinus linteus, J Agric Food Chem, 57, 2147-2154

22. Lee YT, Kim YS (2005) Water-solubility of $\beta$-glucans in various edible mushroom. J Food Sci Nutr, 10, 294-297

23. Ballance GM, Manners DJ (1978) Structural analysis and enzymic solublization of barley endosperm cell-walls. Carbohydr Res, 61, 107-118

24. Lee SH, Jang GY, Kim KJ, Lee MJ, Kim TJ, Lee JS, Jeong HS (2012) Effect of temperature, solvent concentration, and $\mathrm{pH}$ on the $\beta$-glucan extraction. Korean J Food Nutr, 25, 871-877

25. Huang D, Ou B, Prior RL (2005) The chemistry behind antioxidant capacity assays. J Agric Food Chem, 53, 1841-1856

26. Kwoen DJ, Youn SJ, Cho JG, Choi UK, Kang SC (2006) Antioxidant activities and biological properies of Phellinus linteus extracts according to different extraction methods. Korean Soc Appl Biol, 49, 91-96

27. Middleton E, Kandaswami C, Theoharides TC (2000) The effects of plant flavonoids on mammalian cells : implications for inflammation, heart disease, and cancer. Pharmacol Rev, 52, 673-751

28. Kang JY, Ibrahim KE, Juvik JA, Kim DH, Kang WJ (2006) Genetic and environmental variation of glucosinolate content in Chinese cabbage. HortScience, 41, 1382-1385

29. Kim JO, Jung MJ, Choi HJ, Lee JT, Lim AK, Hong JH, Kim DI (2008) Antioxidative and biological activity of hot water and ethanol extracts from Phellinus linteus. J Korean Soc Food Sci Nutr, 37, 684-690 